\title{
Analysis of Selected Aspects of Turned Bearing Rings Regarding Required Workpiece Qua- lity
}

Josef Sedlak, Pavel Tropp, Josef Chladil, Karel Kouril, Ales Polzer, Karel Osicka

Department of Machining Technology, Institute of Manufacturing Technology, Faculty of Mechanical Engineering, Brno University of Technology, Technická 2896/2, Brno 616 69, Czech Republic. E-mail: sedlak@fme.vutbr.cz, TroppPavel@seznam.cz, chladil@fme.vutbr.cz, kouril.k@fme.vutbr.cz, polzer@fme.vutbr.cz, osicka@fme.vutbr.cz

An article deals with an analysis of selected aspects of heat-treated bearing rings during machining and comes up with a solution (a machining operation) leading to improving efficiency of a machining process (i.e. an elimination of a generally expensive cutting technology when the same surface integrity is kept) lying in the series of samples that would be tested experimentally under university conditions (a workroom C2 of Department of Machining Technology FSI VUT in Brno) using a CNC turning lathe SP $280 \mathrm{SY}$.

A theoretical part focuses on a characteristics and analysis of a given component including an applied material $100 \mathrm{Cr} 6$ from which bearing rings are made. A practical part deals with an analysis and evaluation of a residual tension in a surface layer (Barkhausen noise: BN) using the device Rollscan 350. The article also comes up with a solution of an issue of surface integrity after a turning operation of bearing rings. The surface integrity is analysed with a touch measuring device (the device with an inductive sensor Form Talysurf Intra - Taylor Hobson) and a contactless device Talysurf CCI Life - Taylor Hobson.

The article ends with an analysis and evaluation of assessed aspects applied during turning of heat-treated bearing rings regarding the required workpiece quality.

Keywords: Bearing Rings, 100Cr6, Turning Operation, Workpiece Quality, Surface Integrity, Residual Tension

\section{Acknowledgement}

The research was supported and co-financed from a project of Ministry of Industry and Trade of the Czech Republic from a grant FR-TI4/247 Research and Development of Construction and Technology of Energetically Efficient Rolled Bearings with Brass Cage.

This expert article called "Production of Axle Bearing" was made as a part of a forthcoming international project of a company ZKL, a.s. which will be launched to the program HORIZONT 2020, more precisely to a tool "Fast Track to Innovation“. Three partners participate this program: ZKL, a.s. - CZ, PROFIROLL TECHNOLOGIES, GmbH SRN, CAF - ESP. The project preparation was realized with a support of the Branch Contact Organization for Research of New Technologies abbreviated as “OKO-NovaTech" financed from the state budget via a program EUPRO II of the Ministry of Education, Youth and Sports.

\section{References}

[1] FR-TI4/247, Research and Development of Construction and Technology of Energetically Efficient Roller Bearings with Brass Cage, (2012 to 2015, MPO Czech Republic). Leader: doc. Ing. Josef Chladil, CSc.

[2] SEDLAK, J., TROPP, P., CHLADIL, J., OSICKA, K., SLIWKOVA, P. (2015). High- Speed Cutting of Bearing Rings from Material 100Cr6. Manufacturing TECHNOLOGY, 2015, Vol. 15, No. 5, p. 899-908. ISSN 1213-2489.

[3] TROPP, P. (2015). High-Speed Cutting of Bearing Rings from Material 100Cr6. Brno. Master's Thesis. Brno University of Technology, Faculty of Mechanical Engineering, Department of Machining Technology. 92 pp., 6 pp. Appendices. Supervisor doc. Ing. Josef Sedlak, Ph.D.

[4] Bohdan Bolzano, Ltd. Czech Republic. Material List of Steel 14 109. [Online]. (C) 2015. August 2003 [seen $6^{\text {th }}$ June 2015]. Available at: http://www.bolzano.cz/.

[5] Low-alloyed Construction Steel Class 14, Their Composition and Heat Treatment. TumliKOVO: Technology of Mechanical Machining of Metals. [Online]. 2015 [seen 24 ${ }^{\text {th }}$ April 2015]. Available at: http://www.tumlikovo.cz/nizkolegovane-konstrukcni-oceli-tridy-14-jejich-slozeni-a-tepelne-zpracovani/.

[6] SEDLAK, J., FISEROVA, Z., CHLADIL, J., ZEMCIK, O., DVORACEK, J. (2013). Influence of Lubricants on Durability of Roller Bearings. Journal PROCEEDINGS IN MANUFACTURING SYSTEMS, Vol. 8, No. 4, p. 213220. ISSN 2067-9238.

[7] ZEMCIK, O., CHLADIL, J., OTOUPALIK, J., SEDLAK, J. (2013). Changes in Surface Layer of Rolled Bearing Steel. Journal PROCEEDINGS IN MANUFACTURING SYSTEMS, Vol. 8, No. 2, p. 99-104. ISSN 2067-9238. 
[8] OSICKA, K., FISEROVA, Z., OTOUPALIK, J. (2015). Influence of Cutting Tool Overhangs at Machining of Hardened Steels. Manufacturing TECHNOLOGY, Vol. 15, No. 2, p. 188-191. ISSN 1213-2489.

[9] SECO Tools. SECO Tools. [Online]. 2015 [seen $11^{\text {th }}$ May 2015]. Available at: https://www.secotools.com/.

[10] NESLUSAN, M. (2013). Monitoring of Surface Integrity after Cutting of Alloyed Bearing Steels with Use of Barkhausen Noise. Žilina: University of Zilina, Mechanical Faculty. 23 p.

[11]DURSTOVA, Z., MICIETA, B., CILLIKOVA, M., NESLUSAN, M., MRAZIK, J. (2014). Non-destructive Magnetic Evaluation of Ground Surfaces Made of Bearing Steel of Variable Hardness. Manufacturing TECHNOLOGY, 2014, Vol. 14, No. 3, p. 297-303. ISSN 1213-2489.

[12] HRABOVSKY, T., NESLUSAN, M., MiCIETA, B., ClliKOVA, M., MICIETOVA, A. (2014). Barkhausen Noise Emission of Surfaces Produced by Hard Milling Process. Manufacturing TECHNOLOGY, Vol. 14, No. 1, p. 17-23. ISSN 1213-2489.

[13] JANKOVYCH, R., HAMMER, M., HARCARIK, M. (2015). Bore Quality of Shotgun Barrel Blanks. MM Science Journal, Vol. 2015, No. December, p. 728-730. ISSN 1805-0476.

[14] JANKOVYCH, R., BUDIK, T., HAMMER, M. (2015). Operational Limits in Vibration Diagnostics. Advances in Intelligent Systems and Computing, Vol. 1, No. 393, p. 13-18. ISSN 2194-5357.

[15] MOURAlOVA, K., KOVAR, J. (2015). Quality of Dimensions Accurancy of Components After WEDM Depending on the Heat Treatment. MM Science Journal, Vol. 2015, No. 4, p. 790-793. ISSN 1803-1269.

[16] MOURAlOVA, K., DVORAKOVA, J., DVORAK, J., KOVAR, J., KARPISEK, Z., SLIWKOVA, P. (2015). Experimental Analysis on Machinability of Aluminium Alloy Using WEDM Technology. MM Science Journal, Vol. 2015, No. 4, p. 722-727. ISSN 1803-1269.

[17] MOURALOVA, K., BEDNAR, J., KOVAR, J. (2015). Soft optimization of significant process parameters of WEDM: A result for Steel 16MnCr5. In Mendel 2015 - 21st International Conference of Soft Computing - Mendel Journal Series. Mendel Journal series. p. 201-204. ISSN 1803-3814.

[18] DVORAK, J., DVORAKOVA, J., MOURAlOVA, K. (2015). Application of Fuzzy Logic in Analysis of Input Parameters in AWJ Technology. In Mendel 2015 - 21st International Conference of Soft Computing - Mendel Journal Series. Mendel Journal series. p. 97-104. ISSN 1803-3814. 